\title{
Analisis Video Share To Video Views Ratio Tiktok Pada 5 Brand Fashion Termahal di Dunia
}

\author{
Arista Dewi Halima \\ halimaarista@gmail.com
}

\section{1.pendahuluan}

Teknologi informasi dan komunikasi yang telah berkembang dengan pesat mampu menghantarkan manusia untuk menciptakan bentuk baru dalam cara berkomunikasi serta berinteraksi melalui media sosial. Media sosial memberikan pengaruh yang cukup besar, saat ini media sosial diajadikan sarana berkomunikasi dalam setiap aktifitas keseharian bersosial di masyarakat. Komunikasi tidak hanya dapat dilakukan secara fisik, tetapi juga dapat dilakukan dengan menggunakan berbagai aplikasi media sosial di dunia maya. Keunggulan layanan aplikasi sosial media adalah memberikan ruang komunikasi dua arah antara konsumen-perusahaan dan konsumen-konsumen.

Dengan pesatnya perkembangan teknologi media sosial, telah memberikan dampak terhadap situs-situs komunikasi, dari yang awalnya hanya sekedar email dan chatting, saat ini sudah banyak jejaring media sosial yang bisa digunakan sebagai alat komunikasi. Contoh aplikasi sosial media yang memiliki banyak pengguna saat ini yaitu Tiktok. Tiktok adalah sebuah jaringan sosial dan platform video musik Tiongkok yang dluncurkan pada September 2016 oleh Zhang Yiming, pendiri Toutiao. Aplikasi tersebut membolehkan para pemakai untuk membuat video musik pendek mereka sendiri. Ada pun fitur fitur di tiktok adalah menambahkan musik, pakai stiker dan effect,filter,timer dan beautify.

Kehadiran media sosial tiktok dapat membangun sebuah brand, Tiktok juga dapat membangun personal branding pemiliknya (Juli 2021). Di Indonesia terdapat 30,7 juta pengguna Tiktok yang aktif sehingga menjadikan indonesia sebagai negara dengan pengguna Tiktok tersebar didunia. Maraknya jumlah penggunaTiktok aktif di Indonesia tentu dapat memberikan peluang bagi brand untuk menjadikan platfrom ini sebagai platfrom social media marketing. Cukup bnyak akun perusahaan-perushaan terkenal yang ada pada Tiktok, contohnya seperti ARMANI, GUCCI, LOUISVUITTON, PRADA, BURBERRY. (“5 Brand termahal di dunia Q1-2021 - Selluler.ID”n.d).

Penelitian ini menggunakan metode eksploiratif kuantitatif. Penelitian ini hanya berfokus untuk menghitung Ratio Ratio yang ada pada tiktok. Tujuan dari penelitian ini adalah mengetahui kredibilitas performa dari akun Tiktok 5 Brand fashion termahal di dunia menggunakan Video Share To Video Views Ratio 


\section{Hasil dan pmbahasan}

Akun tiktok dari 5 Brand Fashion Termahal di Dunia di antaranya:

\section{ARMANI}

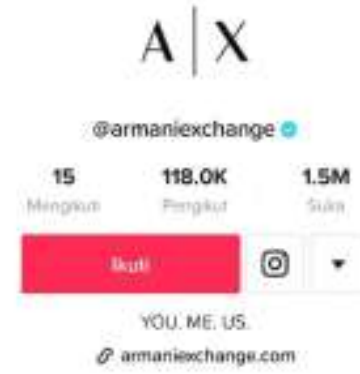

AKUN TIKTOK ARMANI

https://vt.tiktok.com/ZSeY1yvnd/

\section{GUCCI}

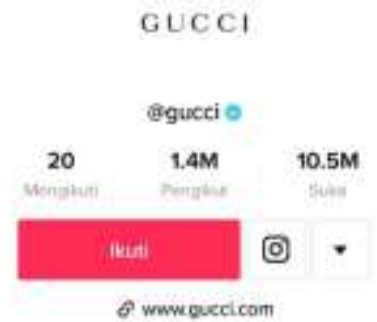

AKUN TIKTOK GUCCI

https://vt.tiktok.com/ZSeY1MRDM/

\section{LOUISVUITTON}

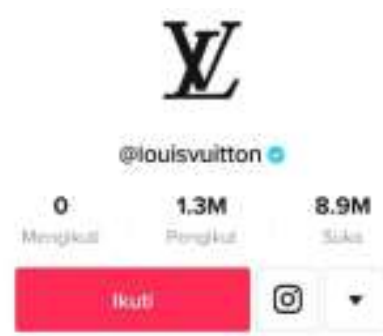

AKUN TIKTOK LOUISVUITTON

https://vt.tiktok.com/ZSeY1hLC7/ 


\section{PRADA}

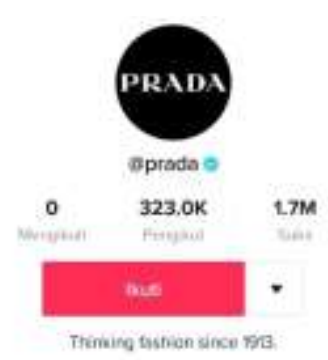

AKUN TIKTOK PRADA

https://vt.tiktok.com/ZSeY1No4o/

\section{BURBERRY}

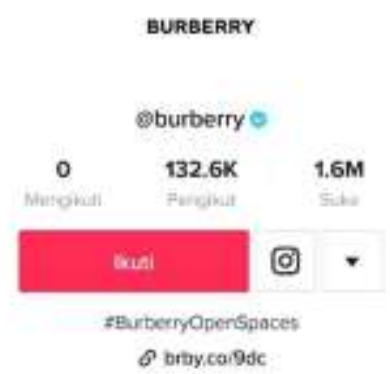

AKUN TIKTOK BURBERRY

https://vt.tiktok.com/ZSeY1j1QH/

Dari kelima akun TikTok Top 5 Brand fashion termahal di dunia, peneliti menemukan nilai dari masingmasing variabel yang ada untuk menghitung rasio Video.

share to Video Views dari setiap akun. Pada akun TikTok terdapat 7 variabel, diantaranya yaitu:

1. Likes

2. Followers

3. Following

4. Video Likes

5. Video Comments

6. Video Share

7. Video Views

Dari ketujuh variabel tersebut peneliti hanya fokus untuk menemukan hasil dari 2 variabel, yaitu:

1. Video share 


\section{Video View}

Dari kedua variabel tersebut kemudian dianalisa sehingga menemukan nilai rata-rata dari variabel video share dan variabel video views. Untuk menghitung nilai rata-rata dari variabel video share dan variabel video views yaitu dengan cara mengambil minimal 10 postingan kemudian di hitung sehingga menemukan nilai rata-rata dari masing-masing variabel. Berikut merupakan tabel nilai rata-rata dari masing-masing brand fashion termahal di dunia, yaitu:

tabel 1 Analisa rata rata nilai variabel Video Share To Video Views Ratio Tiktok Pada akun Brand armani

\begin{tabular}{|c|r|r|}
\hline No. & \multicolumn{1}{|c|}{ Share } & \multicolumn{1}{c|}{ Views } \\
\hline 1 & 2 & 935 \\
\hline 2 & - & 853 \\
\hline 3 & 4 & 2,036 \\
\hline 4 & 2 & 1,842 \\
\hline 5 & 1 & 4,344 \\
\hline 6 & 2 & 1,666 \\
\hline 7 & 3 & 1,193 \\
\hline 8 & 2 & 982 \\
\hline 9 & - & 839 \\
\hline 10 & 6 & 1,047 \\
\hline Total & 2 & $\mathbf{1 , 5 7 3 . 7}$ \\
\hline
\end{tabular}

Tabel 2. Analisa rata rata nilai variabel Video Share To Video Views Ratio Tiktok Pada akun Brand gucci

\begin{tabular}{|c|r|r|}
\hline No & \multicolumn{1}{|c|}{ Share } & \multicolumn{1}{c|}{ Views } \\
\hline 1 & 42 & 28,400 \\
\hline 2 & 12 & 26,600 \\
\hline 3 & 63 & 28,600 \\
\hline 4 & 131 & 123,400 \\
\hline 5 & 51 & 76,000 \\
\hline 6 & 77 & 93,300 \\
\hline 7 & 35 & 48,800 \\
\hline 8 & 59 & 50,300 \\
\hline 9 & 65 & 54,400 \\
\hline 10 & 197 & $1,200,000$ \\
\hline Total & 73 & $\mathbf{1 7 2 , 9 8 0 . 0}$ \\
\hline
\end{tabular}

Tabel 3. Analisa rata rata nilai variabel Video Share To Video Views Ratio Tiktok Pada akun brand louisvuitton 


\begin{tabular}{|c|r|r|}
\hline No. & \multicolumn{1}{|c|}{ share } & \multicolumn{1}{l|}{ Views } \\
\hline 1 & 79 & $1,600,000$ \\
\hline 2 & 133 & $4,600,000$ \\
\hline 3 & 343 & $3,900,000$ \\
\hline 4 & 69 & 115,000 \\
\hline 5 & 72 & 101,800 \\
\hline 6 & 98 & 117,400 \\
\hline 7 & 87 & 254,800 \\
\hline 8 & 66 & 313,500 \\
\hline 9 & 183 & $4,200,000$ \\
\hline 10 & 145 & $3,000,000$ \\
\hline Total & $\mathbf{1 2 8}$ & $\mathbf{1 , 8 2 0 , 2 5 0 . 0}$ \\
\hline
\end{tabular}

Tabl 4. Analisa rata rata nilai variabel Video Share To Video Views Ratio Tiktok Pada akun brand prada

\begin{tabular}{|c|r|r|}
\hline No. & \multicolumn{1}{|c|}{ Share } & \multicolumn{1}{c|}{ Views } \\
\hline 1 & 93 & $3,400,000$ \\
\hline 2 & 69 & $2,700,000$ \\
\hline 3 & 118 & $7,400,000$ \\
\hline 4 & 77 & $3,200,000$ \\
\hline 5 & 163 & $2,800,000$ \\
\hline 6 & 167 & $7,600,000$ \\
\hline 7 & 408 & $11,400,000$ \\
\hline 8 & 58 & $1,300,000$ \\
\hline 9 & 37 & 724,800 \\
\hline 10 & 112 & 42,500 \\
\hline Total & $\mathbf{1 3 0}$ & $\mathbf{4 , 0 5 6 , 7 3 0 . 0}$ \\
\hline
\end{tabular}

Tabel 5. Analisa rata rata nilai variabel Video Share To Video Views Ratio Tiktok Pada 5 akun brand BURBERRY

\begin{tabular}{|c|r|r|}
\hline No. & Share & \multicolumn{1}{c|}{ Viewers } \\
\hline 1 & 228 & $5,800,000$ \\
\hline 2 & 7 & 5,584 \\
\hline 3 & 42 & $1,400,000$ \\
\hline 4 & 62 & $7,000,000$ \\
\hline 5 & 90 & $2,500,000$ \\
\hline 6 & 49 & $5,000,000$ \\
\hline 7 & 7 & 2,603 \\
\hline 8 & 10 & 6,645 \\
\hline 9 & 6 & 5,540 \\
\hline 10 & - & 6,458 \\
\hline Total & $\mathbf{5 0}$ & $\mathbf{2 , 1 7 2 , 6 8 3 . 0}$ \\
\hline
\end{tabular}


Tabel 6.nilai masing masing variabel

\begin{tabular}{|c|c|c|c|c|c|}
\hline Variable & Armani & Gucci & Louis Vuittor & Prada & BurBerry \\
\hline Share & 2 & 73.0 & 128.0 & 130 & 50.0 \\
\hline Views & $1,575.7$ & $172,980.0$ & $1,820,250.0$ & $4,056,730.0$ & $2,172,683.0$ \\
\hline
\end{tabular}

Tabel 7.Hasil perhitungan Rasio Akun tiktok

\begin{tabular}{|c|c|c|c|c|c|c|c|c|}
\hline No. & RATIO & Armani & Gucci & Louis Vuitton & Prada & BurBerry & Karakteristik & 1 \\
\hline 1 & Share to Viewers & 0.0012692771 & 0.00042201410 & 0.00007032 & 0.00003205 & 0.00002301 & Tinggi & - \\
\hline \multicolumn{8}{|c|}{ Total } \\
\hline
\end{tabular}

Tabel 8. Nilai rasio

\begin{tabular}{|c|c|c|c|c|}
\hline Armani & Gucci & Louis Vuittor & Prada & BurBerry \\
\hline 5 & 4 & 3 & 2 & 1 \\
\hline 5 & 4 & 3 & 2 & 1 \\
\hline
\end{tabular}

Kesimpulan

Kesimpulan yang didapat dari ratio video share to video views adalah:

Peringkat pertama: BurBerry

Peringkat kedua: Prada

Peringkat ketiga: Louis Vutton

Peringkat keempat: Gucci

Peringkat kelima: Armani 